\title{
CORRECTION
}

View Article Online

View Journal | View Issue

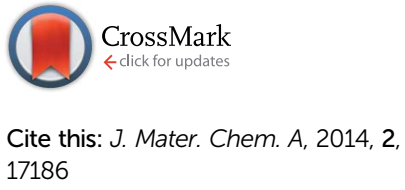

DOI: $10.1039 / c 4 t a 90149 e$

www.rsc.org/MaterialsA

\section{Correction: Synthesis and electrochemistry of pseudocapacitive multilayer fullerenes and $\mathrm{MnO}_{2}$ nanocomposites}

\author{
Muniraj Vedi Kuyil Azhagan, ${ }^{a}$ Mukta V. Vaishampayan ${ }^{a}$ and Manjusha V. Shelke*abc
}

Correction for 'Synthesis and electrochemistry of pseudocapacitive multilayer fullerenes and $\mathrm{MnO}_{2}$ nanocomposites' by V. K. Azhagan et al., J. Mater. Chem. A, 2014, 2, 2152-2159.

Equation 3 on Page 2157 should be as follows ${ }^{1}$

$$
E=\frac{1}{8} C_{\mathrm{s}} V^{2} \cdot \frac{1}{3.6}
$$

where $C_{\mathrm{s}}$ is the specific capacitance per electrode. Therefore, the corresponding sentence in the second column of page number 2157 should be "The maximum energy density obtained for CNO was $5.9 \mathrm{~W} \mathrm{~h} \mathrm{~kg}{ }^{-1}$ with power density of $100.2 \mathrm{~W} \mathrm{~kg}{ }^{-1}$ and the maximum power density was $4.16 \mathrm{~kW} \mathrm{~kg}^{-1}$ with an energy density of $1.6 \mathrm{~W} \mathrm{~h} \mathrm{~kg}{ }^{-1}$. In the case of the composite electrode a maximum power density of $2.25 \mathrm{~kW} \mathrm{~kg}^{-1}$ was achieved at the energy density of $3.56 \mathrm{~W} \mathrm{~h} \mathrm{~kg}^{-1}$ and the maximum energy density of $19.95 \mathrm{~W} \mathrm{~h} \mathrm{~kg}^{-1}$ was achieved at the power density of $144.6 \mathrm{~W} \mathrm{~kg}^{-1}$."

The corresponding Fig. 5 on page 2158 should be as follows:

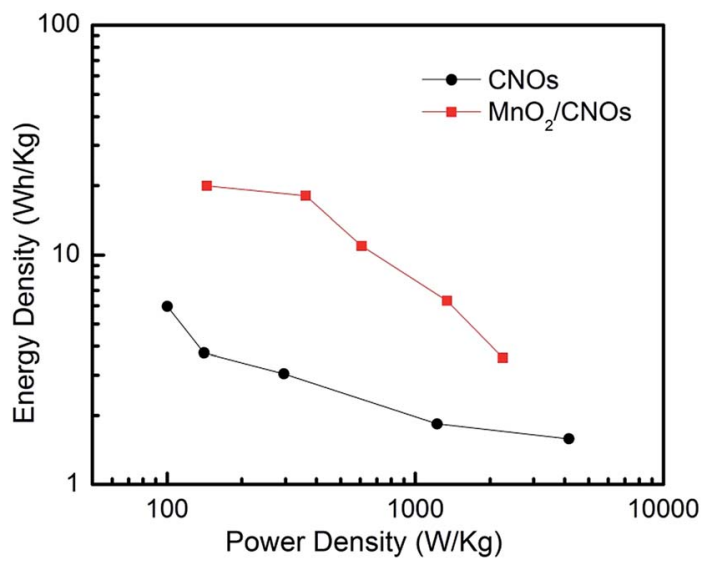

Fig. 5 Ragone plot of the full cell at different current densities (energy density vs. power density) for $\mathrm{CNOs}$ and the $\mathrm{MnO}_{2} / \mathrm{CNO} \mathrm{composite}$.

The Royal Society of Chemistry apologises for these errors and any consequent inconvenience to authors and readers.

\section{References}

1 X. Y. Chen, C. Chen, Z. J. Zhang and D. H. Xie, J. Mater. Chem. A, 2013, 1, 10903. 